Journal title: $\quad$ IJB

Article Number: 429523

Dear Author/Editor,

Greetings, and thank you for publishing with SAGE. Your article has been copyedited, and we have a few queries for you. Please respond to these queries when you submit your changes to the Production Editor.

Thank you for your time and effort.

Please assist us by clarifying the following queries:

\begin{tabular}{|c|c|}
\hline No & Query \\
\hline 1 & Please provide affiliation details for the author. \\
\hline 2 & $\begin{array}{l}\text { Please note that 'language attrition' and 'language reversion' were repeated twice in the keywords list. Therefore, } \\
\text { one has been retained and other has been deleted. Please check. }\end{array}$ \\
\hline 3 & Please provide the postal address for the corresponding author. \\
\hline 4 & 'Fishman (1964)' has been changed to 'Fishman (1966)' to match the reference list. Please check and confirm. \\
\hline 5 & 'Pauwels (1991)' has been changed to 'Pauwels (1986)' to match the reference list. Please check and confirm. \\
\hline 6 & Please provide the appropriate section title for the phrase 'previous section.' \\
\hline 7 & Please check the sentence 'Finally, the possible impact...' for clarity. \\
\hline 8 & Please check the phrase 'got your your accent' for clarity. \\
\hline 9 & 'Fishman (2001)' is not listed in the references. Please provide reference details or allow us to delete the citation. \\
\hline 10 & $\begin{array}{l}\text { 'Ammerlaan (1996)' is not listed in the references. Please provide reference details or allow us to delete the } \\
\text { citation. }\end{array}$ \\
\hline 11 & Table 3 has been changed to Table 4 as per the caption. Please check. \\
\hline 12 & Please mention what the phrase 'the above' refers to for clarity. \\
\hline 13 & $\begin{array}{l}\text { 'Bialystok (2011)' is not listed in the references. Please provide reference details or allow us to delete the } \\
\text { citation. }\end{array}$ \\
\hline 14 & Please check the sentence 'Interestingly, the people ...' for clarity. \\
\hline 15 & Please check the phrase 'at at school' for clarity. \\
\hline 16 & $\begin{array}{l}\text { 'Baetens Beardsmore (2003)' is not listed in the references. Please provide reference details or allow us to delete } \\
\text { the citation. }\end{array}$ \\
\hline 17 & $\begin{array}{l}\text { 'Bönisch-Brednich (2003)' is not listed in the references. Please provide reference details or allow us to delete } \\
\text { the citation. }\end{array}$ \\
\hline 18 & 'Census (2006)' is not listed in the references. Please provide reference details or allow us to delete the citation. \\
\hline 19 & 'Paradis (2004)' is not listed in the references. Please provide reference details or allow us to delete the citation. \\
\hline 20 & Please confirm whether the given funding statement is accurate and correct. \\
\hline
\end{tabular}




\begin{tabular}{|l|l|}
\hline 21 & Please note that the year '2007' has been introduced in this citation. Please check. \\
\hline 22 & Please provide English translation for the book title in reference 'Clyne (1981)'. \\
\hline 23 & Please provide English translation for the book title in reference 'De Jong (1980)'. \\
\hline 24 & Please provide English translation for article title for reference 'Kuiper (2004)'. \\
\hline 25 & Please update 'Sachtleben \& Crezee (in press)'. \\
\hline 26 & Please provide 2-3 sentence biography about the author. \\
\hline & \\
\hline & \\
\hline & \\
\hline & \\
\hline
\end{tabular}




\title{
Language shift and host society attitudes: Dutch migrants who arrived in New Zealand between 1950 and 1965
}

International Journal of Bilingualism $0(0) 1-13$

(C) The Author(s) 2012 Reprints and permission: sagepub.co.uk/journalsPermissions.nav DOI: |0.||77/|3670069||429523 ljb.sagepub.com

(SAGE

\section{Ineke Crezee \\ [AQ: 1]}

\begin{abstract}
A study published in 2010 reported on past and current language use of a group of older Dutch migrants in New Zealand. Dutch migrants were chosen because the researcher was herself a bilingual Dutch-English-speaking migrant and hence in a good position to understand respondents' background and assess their language use in both English and Dutch. Respondents interviewed for the study consisted of 30 retired Dutch migrants, all of whom had arrived in New Zealand between 1950 and 1965 when they were aged between 18 and 35 years. All respondents were living in the Greater Auckland area and were aged between 65 and 92 years at the time of the interview. All respondents were asked questions based on a sociolinguistic life questionnaire and asked about their language use and experiences since migration. Interviews were recorded, and information from interviews and questionnaires was supplemented by data collected from participants' adult children. This article will focus on respondents' comments in relation to their motivation to either maintain their first language (LI) Dutch or shift to their second language (L2) English in the home environment. It appears that external societal attitudes affected respondents' language use in a number of domains, including the home environment.
\end{abstract}

\section{Keywords}

Bilingualism, bilingualism in a migration context, Dutch in New Zealand, host society attitudes, host society expectations, invisible migrants, language attrition, language maintenance, language regression, language reversion, language shift, LI linguistic environment, L2 linguistic environment, migrants, migration, receiving society attitudes, receiving society expectations [AQ: 2]

\section{Introduction}

The focus of this article will be to examine the possible influence of host society attitudes on language choice in a group of older Dutch migrants all of whom had arrived in New Zealand between 1950 and 1965 when they were aged between 18 and 35 years. Previous studies have examined the 
issue of core values (Hulsen, 2000; Smolicz, 1992) in this context; however, anecdotal evidence suggested that the possible influence of host society expectations might also warrant investigation. Data from this article were based on a study involving a sample of 30 older Dutch migrants, which was conducted between 2006 and 2007, when all respondents were of retirement age. All respondents were asked both open and closed questions through a sociolinguistic life questionnaire and asked about their language use and experiences since migration. Subjects were interviewed, and free elicited speech collected during interviews was subjected to multiple linguistic analyses. Data collected were supplemented by information gained through questionnaires completed by respondents' adult children. The latter commented on their parents' language choices during their working lives and following retirement, and on any linguistic features of their parents' spoken English at the time of the study and prior. The study's main focus was language use among older Dutch migrants, with a special focus on possible L2 attrition and L1 reversion; however, the research instruments used yielded a wealth of additional data, not all of which have been submitted for publication.

This article will focus on respondents' comments in relation to their reasons for either maintaining their L1 Dutch or shifting to their L2 English in the home environment. This phenomenon of high rates of language shift among L1 Dutch migrants has been noted in previous studies (Hulsen, 2000; Kuiper, 2004; Roberts, 1999), and various possible explanations have been proposed. This article will also examine some of the findings in the light of these studies, particularly the possible impact of host society attitudes held in the decades between 1950 and 1970 concerning language maintenance among respondents.

\section{Background information}

New Zealand welcomed tens of thousands of Dutch migrants in the 1950s and 1960s. Most migrants were aged between 18 and 35 years on arrival in New Zealand and had reached retirement age by the time of the interviews. Thirty older Dutch migrants were interviewed as part of the study into L1 and L2 use at various stages of their lifetimes following their arrival in New Zealand. Table 1 shows the demographic makeup of the group of respondents in terms of gender, immigration cohort, age on arrival and age at time of interview.

\section{Previous studies}

Migration involves acquiring a second language, unless migrants move to a country whose dominant language is also their own first language. An example of that would be migrants from the United Kingdom migrating to New Zealand. However, in a majority of cases, migration requires either acquisition of a second language or much more extended use of an existing second language in a much wider range of contexts, including the work, education and public domains. Bilingualism in a migrant context has been the subject of many studies, including research focusing on the phenomenon of language maintenance and language shift (Fishman, 1966, 1991)[AQ: 4]and studies focusing on language contact phenomena (e.g. Appel \& Muysken, 1987). A number of studies reported on the high rate of shift from L1 to L2 among Dutch migrants, particularly in the Australian context (Clyne, 1981; Fase, Jaspaert, \& Kroon, 1992; Pauwels, 1986; Seebus, 2008)[AQ: 5]. Other researchers (Hulsen, 2000; Roberts, 1999) examined language maintenance and shift among several generations of Dutch migrants in New Zealand. Hulsen included questions on identity following Smolicz's (1992) suggestion that high rates of language maintenance may be associated with migrants considering language a core value of their identity. 
Table I. Demographic makeup of sample of respondents

\begin{tabular}{lccc}
\hline & Female & Male & All respondents \\
\hline $\begin{array}{l}\text { Immigration cohort } \\
\text { 1950-1954 }\end{array}$ & 10 & 8 & 18 \\
1955-1959 & 5 & 4 & 9 \\
1960-1965 & 3 & - & 3 \\
Age on arrival (years) & & & \\
18-19 & 1 & 1 & 2 \\
$20-24$ & 9 & 4 & 13 \\
$25-29$ & 5 & 4 & 9 \\
$30-34$ & 2 & 3 & 1 \\
$35-39$ & 1 & - & 1 \\
Age at the time of interview (years) & & & 4 \\
$65-69$ & 1 & - & 17 \\
$70-74$ & 3 & 1 & 5 \\
$75-79$ & 10 & 7 & 2 \\
$80-84$ & 3 & 2 & 30 \\
$85-89$ & - & 1 & 1 \\
$90-95$ & 1 & 10 & \\
All & 20 & & \\
\hline
\end{tabular}

In a previous publication (Crezee, 2010), the author reported on language use among older Dutch migrants. Respondents were asked about language use at various key stages of their lives post migration to New Zealand, including language choice in the home and work domains and factors, which had played a role in language choice. Questions on identity and core values were not included in the questionnaire; however, issues of identity were sometimes brought up spontaneously by respondents during the interview. This article is based on precisely such issues of identity, as respondents very clearly expressed their (initial) desire to be accepted as New Zealanders, only to find later on that they were never quite accepted because they were told they 'still had an accent'. The pronunciation issues will be further examined in another article (Sachtleben \& Crezee, in press).

\section{Research sample}

All respondents were older bilingual Dutch-English-speaking migrants who were able to comfortably express themselves in English at the time of the interview. All respondents $(n=30)$ had migrated between 1950 and 1965, with ages varying from 18 to 39 years at the time of migration, with the majority $(n=24)$ aged between 18 and 29 years. A majority of respondents $(70 \%)$ had received some English instruction before coming to New Zealand, varying from private classes to a number of years of classroom instruction. Self-assessed levels of English proficiency on arrival in New Zealand varied accordingly. Following migration, all respondents had either acquired English or improved their English through immersion in English-speaking New Zealand society.

\section{New Zealand society in the 1950 s}

The Dutch were not the very first non-British migrants to be allowed into New Zealand. Small numbers of others, including Jewish refugees and Polish migrants, had started to arrive in New 
Zealand in the 1930s and 1940s. The New Zealand government of the 1940s and 1950s pursued a policy whereby it displayed a definite preference for Anglophone migrants. In 1939, the government had allowed three young Dutch tradesmen to come to New Zealand to work, as a sort of experiment (Schouten, 1992). These three had assimilated well and very importantly this appeared to have opened the proverbial door to other migrants from the Netherlands.

King (2003) quotes Adelson when he describes the country the new migrants arrived in as a country whose residents had 'turned in on themselves' (King, 2003, pp. 414-415). It is important to add in this context that during the 1950s, rural Maori had been moving to larger towns and cities in New Zealand where they had been confronted with the expectation that they 'blend in' with Pakeha (European) language and culture (King, 2003). It is not surprising, therefore, that Dutch migrants who arrived in New Zealand in the early 1950s onwards also experienced a host society expectation that they assimilate and adapt to the ways of Anglophone New Zealanders.

\section{Methodology}

As stated in the previous section[AQ: 6], respondents interviewed for the study consisted of a total of 30 older Dutch migrants, all of whom had arrived in New Zealand between 1950 and 1965. Sample selection took place using the 'snowballing' method, where one respondent refers the researcher on to another potential interviewee. Ethics approval was sought to work with this group of older adults. Schmid's (2004) suggestions for the most appropriate methodological approaches in the field of language attrition and possible language reversion were followed where practicable.

All respondents were interviewed by the researcher at home in their own environment, with interviews recorded on an iAudio X5 digital recorder. During the interviews, respondents were asked a range of questions from a sociolinguistic life history questionnaire (cf. also Taumoefolau, Starks, Davis, \& Bell, 2002). Questions covered a range of topics, including social background in the Netherlands, educational background, manner of English acquisition (cf. Ellis, 1994), L1 and L2 maintenance and use of pre- and post-retirement. Questions also explored respondents' exposure and use of both the L1 and L2 in a variety of domains, such as family, work and friends. The questionnaire also asked about host society attitudes towards English as additional language (EAL) speakers at the time of migration and at the time of interview. Information from the questionnaire was supplemented by elicited free speech, which was recorded during the interviews and by data obtained from participants' adult children. The latter was deemed important as there is often a discrepancy between reported and observed linguistic behaviour. It was assumed that these older migrants' adult children would be quite critical when it came to their parents' linguistic behaviour, and this was indeed found to be the case. Respondents had been divided up into two groups, to see whether their predominant linguistic environment post-retirement, might impact on the extent of L1 reversion, if any. However, this division is not reflected here, as it was not deemed relevant within the parameters of this article.

This article will focus specifically on participants' rates of language shift and reasons reported for the same, including host society attitudes at the time they arrived in New Zealand. As stated previously, the questionnaire did not contain questions about cultural values and identity; however, the issue of identity sometimes spontaneously surfaced during the interviews.

\section{Findings}

This section will start with some information on the respondents' reports of language spoken at home at various stages of their life in New Zealand post migration. This will be followed by an overview of respondents' statements as to why they had chosen to either maintain the use of their 
Table 2. Amount of Dutch spoken with friends initially

\begin{tabular}{lcc}
\hline & $N=30$ & Percentage \\
\hline All the time & 0 & 0 \\
Most of the time & 6 & 20 \\
Fair amount & 9 & 30 \\
Very little & 12 & 40 \\
None & 3 & 10 \\
\hline
\end{tabular}

first language (L1) Dutch at home or had shifted to the use of their second language (L2) English. Finally, the possible impact of host society attitudes on language choices, as reported by respondents, will be examined, and their perception of whether host society attitudes had changed by the time of the interview.[AQ: 7 ]

\section{Language spoken in a range of domains}

New Zealand government policy in the 1950s (Schouten, 1992) consisted in spreading Dutch migrants across the country as much as possible, especially in the early years of Dutch migration (Schouten, 1992), thus reducing opportunities to speak Dutch outside of the home in the social domain. Hence, not surprisingly, almost half of respondents reported that they had spoken 'very little' Dutch with friends initially. Table 2 shows the amount of Dutch spoken with friends initially, that is, shortly after arriving in New Zealand.

In the work domain, respondents had used their L2 first and foremost, even when speaking with Dutch workmates. One respondent recounted how:

(1) Well, in, when we were railways, see, there was all about eight people, eight, except the... say the leader of the gang. We were, we were a gang more or less, you know, and you had the ...yeah, he was [..] a New Zealander. And then er it was four Dutchmen and er but the way we did made a difference too, because a lot of Dutch people they started to work together and they kept on talking Dutch. And we did, ja, in a way we did when the four of us were together, but during the day, you know, because that was very strict: 'No Dutch! No Dutch!'

It was clear from responses to the sociolinguistic life questionnaire that the respondents' experience had been shared by many others. A majority of interviewees felt that New Zealanders wanted them to speak English all the time, even in a private environment, such as when they were on vacation. One respondent recounted being at a camp ground within the first year of arriving in New Zealand and talking to his children in Dutch. He said a New Zealander stopped him saying, 'I don't want you to speak Dutch to those children.' When he asked why not, she said, 'Because I cannot understand it.' It should be added that aside from these somewhat less positive experiences, most respondents reported having received invaluable help and support from New Zealand friends and workmates early on and having forged lifelong friendships as a result.

Table 3 shows that most respondents had felt a certain pressure from members of the host society to speak English most of the time, with only a few saying host society members had found it okay for them to speak Dutch some of the time.

Several respondents felt that New Zealanders seemed to think that they were talking about them whenever Dutch people were speaking to each other in Dutch. One fairly outspoken female respondent said: 
(2) And suspicious. Suspicious! If you if you have if you have an er if you talk just like MET JOU [with you] and somebody comes just on the door and 'T IS EEN KIWI [it's a Kiwi] and they hear you talk they don't like that. [ ... ] No, yeah but they always think you talk about them! And I said that is not true!

Respondents said they tried hard to assimilate and become New Zealanders. A female respondent recounted all the things she had done to try and fit in, 'for the kids' sake', before eventually realising that even after living and working in her adopted country for 50 years, New Zealanders were still commenting on her accent, making her feel they did not truly accept her as a New Zealander. At that point, she decided that she would never be accepted as a New Zealander and said she was now proud of being Dutch (example 3).

(3) JA [yes], in the town JA, JA [yes, yes]. But then the aldest one OU... [old...] MET [with], DIE [she] go to school and: "I want to be an Kiwi. I want to be a New Zealander." I want to be, for my kids' sake. Some people want to keep Dutch up, but I know how difficult it was, this I go to school, I belongs to the lunches, library and I been in the committee, I did everything what I ... ... in the community. I want to be...very good neighbours. I want to be... a New Zealander. JA, you have to. I did. That's what I thought I have to. It's very wrong in other people attitude. And mine attitude was here in NIEUW-ZEELAND [New Zealand] for the kids' sake....JA. At first I never want to be Dutch, I want to be New Zealand, but I find out I'm Dutch. And I'm born in Holland and that's it. I'm quite proud.

Another female respondent recounted a similar experience and how she too had finally decided to accept that she was not going to be accepted as a New Zealander based on the fact that she still had an accent:

(4) JA, IK ZEG ALTIJD [Yes, I always say], you know. WAAR KOM JIJ VANDAAN [where are you from]? IK ZEG, OH, VAN HOLLAND [I say, oh, from Holland] and from the Netherlands, or whatever. Oh, you still got your your accent! I said: that makes me different from the Kiwis. Fine![AQ: 8]

Yes, I always say, you know. Where are you from? I say, oh, from Holland] and from the Netherlands, or whatever. Oh, you still got your your accent! I said: that makes me different from the Kiwis. Fine!

However, it was clear that respondents were very disappointed at what they perceived to be quite thoughtless comments, which seemed to discount all their efforts to become New Zealanders, including the fact that a majority had even gone so far as to switch to the use of English at home.

Table 3. Host society attitudes to speakers of languages other than English - all respondents

\begin{tabular}{lr}
\hline & All \\
\hline Host society wanted us to speak L2 ALL the time & 20 \\
Host society wanted us to speak L2 MOST of the time & 8 \\
Host society did not mind us using LI SOME of the time & 2 \\
Total & 30 \\
\hline
\end{tabular}


Table 4. Amount of Dutch spoken at home initially

\begin{tabular}{lcc}
\hline & $N=30$ & Percentage \\
\hline All the time & 2 & 7 \\
Most of the time & 19 & 63 \\
Fair amount & 3 & 10 \\
Very little & 3 & 10 \\
None & 3 & 10 \\
\hline
\end{tabular}

Table 5. Influence of host society on decision as to language spoken at home

\section{Language spoken at home}

Fishman (1991, 2001)[AQ: 9]emphasised the importance of the language spoken in the home domain in relation to language maintenance and survival. As stated, numerous studies revealed the extent of language shift among first- and second-generation Dutch migrants (Ammerlaan, 1996 [AQ: 10]; Pauwels, 1986; Roberts, 1999) with parents unable to communicate in their L1 with their own children and grandchildren. Respondents were asked first of all which language they had spoken at home at the time they first arrived in New Zealand. Table 4[AQ: 11] shows that even at that stage, only a small proportion of respondents reported having spoken Dutch at home even initially.

A number of studies (e.g. Kuiper, 2004) show that many Dutch immigrants in fact shifted to the use of English at home within the first few years of arriving in New Zealand. In this study, a majority of the 30 respondents $(n=18)$ stated that they had shifted to the use of English at home, compared to $40 \%$ who reported to have maintained Dutch. Responses to the questionnaires revealed that many respondents had shifted to the use of English, their L2, at home as soon as the children started attending school. The current study showed one overwhelming reason for such a shift to be a strong desire to ensure their children could take part in the dominant mode of education and culture. Table 5 shows respondents' replies when asked whether the host society had any influence as to what language they chose to speak with their children at home.

Responses to the questionnaires showed that in almost every case, this language shift had followed advice given by a person in a position of authority, who had warned respondents that their children might lag behind academically unless the parents spoke English to them at home. Two respondents said that the shift to the use of English at home had occurred as a result of older siblings attending school and subsequently speaking English to the younger siblings who were still at home. Two other respondents said they had consciously shifted to English because they knew of other L1 Dutch-speaking children who were singled out and bullied at school because of it. When asked whether English-speaking New Zealanders had any influence on what language they decided to speak at home, almost half of all respondents mentioned advice given to them by New Zealand professionals (Table 6).

The above also shows the attitude on the respondents' part as to how best to act as responsible parents.[AQ: 12] They had just arrived in a country where the majority of people, even professionals, were monolingual. There was not much information on bilingualism available at the time, 
Table 6. Influential figures who had advised respondents to shift to the use of the L2 at home

\begin{tabular}{lc}
\hline Influential person who advised to shift to use of $L 2$ at home & All $^{\mathrm{a}}$ \\
\hline Teacher & 12 \\
Plunket nurse & 2 \\
Doctor & 1 \\
Alla & $14^{\mathrm{a}}$ \\
\hline
\end{tabular}

All = only those respondents who had switched to the use of the L2 English at home on the advice of New Zealand professionals.

aPlunket nurse - New Zealand child health nurse, checking the health and development of children aged between 0 and 5 years of age and advising parents on child development.

and even the local Maori people were discouraged from using their own indigenous language, Te Reo Maori (King, 2003). The respondents were in a new country and put their trust in the advice of those who were in the positions of authority.

As one respondent put it:

(5) So...TOTDAT WE EIGENLIJK STOPTEN MET WERKEN GINGEN WE PRAKEN WE ALTIJD English, YEAH. WANT DAT ZEIDEN ZE TOEN WIJ, HÈ, ONS EERSTE KIND NAAR SCHOOL GING, HET EERSTE WAT ONS DE teacher ZEI IS: SPREEK GEEN HOLLANDS TEGEN JE KINDEREN, it stops their education. EN TOEN GELOOFDE JE DAT. Yeah, that's what they told us." If they didn't ... if they should have learnt something, the first thing they said was: oh, yes, but the parents are Dutch.

So...until we stopped working, we really always spoke English, yeah. Because that's what they said, when our first child started school. The first thing the teacher said to us was: don't speak Dutch to your children. It stops their education. And at the time we believed that. Yeah, that's what they told us. If they didn't ... if they should have learnt something, the first thing they said was: oh, yes, but the parents are Dutch.

Interestingly, the people whose advice these bilingual migrants heeded were most probably monolingual, and their recommendations, however well-intentioned, have since been proven to be incorrect, as studies have now shown that bilingualism may in fact be very beneficial for children's academic success (cf. Bialystok, 2011; McCaffery, 1998)[AQ: 13].[AQ: 14]A second, less frequently mentioned $(n=2)$ but no less important rationale given for shifting to the use of the L2 at home, was a desire on respondents' part to avoid their children being bullied at school for sounding different to the English-speaking New Zealand children. One respondent said:

(6) We had people we knew and er their kids were er you know laughed at at school because they couldn't speak English and I said well it's not going to happen to our kids.[AQ: 15]

It should be noted that the respondent quoted in example (6) spoke English with an accent strongly reminiscent of received pronunciation (RP) herself, which seemed to suggest that she herself had also tried hard to avoid sounding like a non-English-speaking immigrant. Four respondents quoted other reasons for switching to English at home. Two respondents stated they themselves had decided it would be better for the children if they spoke English at home. Two other respondents said that their eldest child had come home from school speaking English and had taught the younger siblings 
who were still at home. Another two respondents said that they themselves had decided that it would be better for their children if they switched to the use of English at home. The fact that a majority $(\mathrm{n}=18)$ switched from Dutch to English in the home environment seems to show the respondents' desire to assimilate for the sake of their children's future. This belies a pragmatic attitude, which may be said to be quite characteristic not just of Dutch migrants, but of Dutch people in general (Vossestein, 2005). Previous studies (e.g. Hulsen, 2000) have examined Smolicz's argument that language may not be a core value for speakers of Dutch and other languages such as German and Gujarati; however, the influence of host society attitudes in this context has not been given the attention it deserves.

In contrast, a small number of respondents stated that they had maintained use of the Dutch language at home. One female respondent gave her reasons for this as follows:

\section{(7) JA, IK BEN HOLLANDS THUIS BLIJVEN PRATEN. JA, EN IK VIND OOK 'T IS IDIOOT ALS DIE KINDEREN HUN HOLLANDSE, HUN MOEDERTAAL VERGETEN. MAAR ZE GEVEN ALLEMAAL IN 'T ENGELS WEL ANTWOORD HOOR.}

Yes, well I just kept speaking Dutch at home. Well, I think it's ridiculous if the children forget their Dutch, their mother tongue. But [I must say] they do always reply in English.

Ten respondents had kept up Dutch at home. One had also received advice from teachers to stop speaking Dutch to her children at home, but being multilingual herself, had spoken up against their advice:

(8) Oh, yeah, but we had a bit more skills, don't forget. All the people who came here, they hadn't had much schooling in Holland, because the schools were taken by the Germans, there were no teachers for, let us say, for two years, and Then, well, in the beginning, the schools still had to be organized, so a lot of these people immigrated in the early years and their education is...was fairly poor. And of course that did not help at all. So when somebody talked to them... we could speak English you see, because when we were just in New Zealand, we talked Dutch to our children. And then they said: Oh, you shouldn't speak Dutch to your children. And we could just say: listen: people can speak any kind of foreign language, you know. I have been at the school here, at the High School and ... at the primary school and I used to speak Dutch to them and they said: oh well, you have to speak English to him, you have to speak English to him, and I said: No, that's not necessary, I can speak German, I can speak French, I can speak English, you know. My children are allowed to speak two languages.

Interestingly, this respondent brought up another reason why L1 Dutch parents might have taken the advice of monolingual New Zealand professionals to heart, by pointing out that a lot of Dutch migrants had not had much education, their schooling having been interrupted by the war, with many schools being used as barracks and headquarters by the German army (see also De Jong, 1980).

Some respondents had in fact continued speaking Dutch to some of their children (usually the eldest), but spoke English to other children. It was significant that those whose children spoke Dutch always spoke Dutch to them after their parents' retirement, something that is important when older migrants start reverting back to their first language. Adult children of 9 of the 15 respondents reported that their parents often switched from English to Dutch following their retirement seemingly without noticing it themselves. The adult child of one respondent said, '[Name] lapses into Dutch now without noticing. This has been happening quite a bit more lately'. The influence of the predominantly L1 social environment of this respondent may have been at play here. 
Table 7. Changes in the attitudes of Anglophone New Zealanders towards non-LI-English-speaking migrants

\begin{tabular}{lr}
\hline & All \\
\hline New Zealanders are less tolerant now (2007) & 5 \\
New Zealanders are more tolerant now (2007) & 21 \\
There has been no change in the attitude of New Zealanders & 4 \\
(between 1950s and 2007) & 30 \\
All &
\end{tabular}

\section{Changing attitudes in the New Zealand host society by the early 2 I st century}

When asked whether the attitudes of English-speaking New Zealanders towards speakers of languages other than English had changed, responses varied as shown in Table 7. It is of interest in this context that the 2006 Census showed that some $80 \%$ of the New Zealand population (still) identified with the status of monolingual speaker of English. Even so, Table 7 also shows that a majority of respondents felt that the Anglophone population was more tolerant towards non-English-speaking migrants, and one person attributed this to the fact that 'Kiwis travel more now'. It will be clear from Table 7 that a small number of respondents (17\%) felt that English-speaking New Zealanders had 'hardened' in their resolve that new migrants should all speak English (cf. Baetens Beardsmore, 2003)[AQ: 16], with one respondent commenting that this was probably because more recent arrivals were more likely to keep speaking their own first language within earshot of English-speaking New Zealanders (cf. Kuiper, 2004). Other evidence of somewhat less than welcoming attitudes towards migrants maintaining their own L1 rather than switching to the dominant language of the recipient society has been recorded by Baetens Beardsmore (2003) in the United States context and by Bönisch-Brednich (2003)[AQ: 17] in the New Zealand setting.

The respondent quoted previously added that while she and her husband had always switched to English in the presence of English speakers, more recent migrants did not seem to adhere to this practice.

(9) JA JE PRAAT ENGELS NATUURLIJK ALS D'R ENGELSE MENSEN WEL BIJ ZIJN, GEWOON UIT BELEEFDHEID. MAAR IK DENK WEL'NS ALS JE HIER BIJVOORBEELD BIJ AL DIE greengrocers GAAT, HOE DIE DAAR HUN EIGEN TAAL BLIJVEN PRATEN UH DAAR KOMT GEEN WOORD ENGELS UIT, HOOR.

(10) Well, of course you speak English when English people are around, just as a matter of courtesy. But I sometimes think that when you go to the greengrocers, how they keep speaking their own language, not a word of English from them, you know.

One female respondent commented that (by 2007):

(11) The attitude of people like it used to be like many many years ago if there is a New Zealanders [sic] and they heard you talking Dutch ... they really fell over, aye? Now, that attitude has changed. People accept it a bit more nowadays, and er you know, they don't fly off the handle as much as they used to do.

While yet another respondent realised that the advice given to L1 Dutch-speaking parents at the time their children went to school in New Zealand had been incorrect, when she stated: 
(12) Oh, when we came first to the country we lived next to a teacher and of course that teacher er gives the advice not to speak Dutch to the children, because it wasn't very good. And of course now they go the other way.

From what followed, it was clear that she appeared to be referring to the fact that more recent thinking is that bilingualism is actually beneficial to children's academic development (cf. Bialystok, 2010; Dreifus, 2011). Several of those who had not maintained their first language at home, now expressed regret at this. Another female respondent said that in hindsight, the Dutch migrants might have been too keen to assimilate and might have ended up being rewarded for their troubles by virtually becoming the invisible migrants (cf. also Bönisch-Brednich, 2003):

(13) No, I think it is because the Dutchies dug deep the moment they arrived in New Zealand and they ... we're totally forgotten. They never talk about Dutchies - they talk about the English, the Scots, the Irish.

A considerable number of respondents were still confronted with and saddened by what they perceived to be comments aimed at excluding them from New Zealand society based on their accents. These comments may be due to the fact that a large majority of New Zealanders identified as being monolingual (Census 2006)[AQ: 18]. Not having experience of second language learning themselves, they were probably ignorant of the fact that any second language learners who learn a second language after the age of 13 years are unlikely to be able to perfectly reproduce the L2 phonological features (Paradis, 2004)[AQ: 19]. It is hoped that the incidence of this sort of comment will come to an end now that more New Zealand children are acquiring first-hand experience of learning a community (rather than a foreign) language in school and now that more New Zealanders are travelling. One respondent summed this up when she said:

(14) Well, when we arrived here I thought the place was round about ten thousand years behind. And they thought that we were stupid, you know, and that is why we were told too, not to work so hard. You're letting us down, don't work so hard. ... But things have improved a little bit since they started travelling. JA, JA. [Yes, yes.] Travelling, Kiwis you know, they travel all over the world around they're coming back after a few years. Yeah, now there is a big difference.

Another respondent agreed, saying:

(15) Well, my knowledge of English was good, but I've got an accent, [...] and I never got rid of it. I never, I tried..... Oh, it has changed a little bit, because if you opened your mouth when we arrived, in sixty-two, they didn't want nothing to do with you - they didn't want to talk with you ever, I think they were scared of you, because you were something from out of the sky, and I think that has changed a bit erm...... people are more like café-style now, they have become more Americanised.

\section{Summary}

Respondents in the study reported on here perceived a wish on the part of members of the host society for them to assimilate into New Zealand language and culture, including in the home environment. In a majority of cases, respondents reported that New Zealanders wanted them to speak English most of the time. Respondents reported that to this day, they would always speak English when there were English speakers present, which confirms Kuiper's (2004) 'earshot theory'. The 
study also confirmed the findings of other studies, which had observed a very quick shift to the use of English in the home environment among Dutch migrants within the first few years after migration. Responses to the questionnaires indicated that respondents had often shifted to the use of their L2 in the home environment following advice given by New Zealand professionals such as teachers and health professionals. Responses also indicated that some respondents were quite sad about the fact that they were still confronted with comments about their accents, as they perceived this to be almost akin to being told they were still not accepted as New Zealanders, in spite of all their efforts to assimilate and in spite of having resided in the country for most of their lifetimes.

Overall though, most respondents felt that by the time they were interviewed for the study between 2006 and 2007 - there had been a change for the better in terms of New Zealand being more accepting of non-standard speakers of English, and they felt this was to the benefit of more recently arrived immigrants. They also stated that more recent arrivals seemed more assertive than they themselves had been in terms of maintaining the use of their first language. It was clear that some migrants regretted the fact that they had not maintained their own first language at home, first when speaking to their children and later when communicating with their grandchildren.

The final words must go to the respondent who had asserted her right to bring up her children bilingually:

(16) I have always ... [...] that they must let the people speak their own language, because what is going to happen when these people are going to be old. They have their English at a later time of their lives so their language will go and they will speak their own language. And the kids will not be able to understand them and that will be very very difficult and a lot of loneliness for those elderly people. And certainly when one of the parents died, the mother or father is on their own and the kids haven't got contact with them, that will cause a heck of a lot of trouble.

\section{Funding}

This research received no specific grant from any funding agency in the public, commercial, or not-for-profit sectors.[AQ: 20]

\section{Acknowledgements}

The author is indebted to the work of De Bot (2007[AQ: 21]; Köpke, Schmid, Keijzer, \& Dostert, 2007) and his thought-provoking work on lifespan development and language attrition and also to Schmid (2004) for her very helpful suggestions relating to the most appropriate methodological approaches in the field of language attrition and possible language reversion.

\section{References}

Appel, R., \& Muysken, P. (1987). Language contact in bilingualism. New York, NY: Edward Arnold.

Bialystok, E. (2010). Global-local and trail-making tasks by monolingual and bilingual children: Beyond inhibition. Developmental Psychology, 46, 93-105.

Clyne, M. (1981). Second language attrition and first language reversion among elderly bilinguals in Australia. In M. Meid \& K. Heller (Eds.), Sprachkontakt als Ursache von Veränderungen der Sprach- und Bewusstseinsstruktur (pp. 25-32). Innsbruck, Austria: Institut für Sprachwissenschaft, Universität Innsbruck.[AQ: 22]

Crezee, I. (2010). Investigating possible L2 attrition and L1 reversion in older migrants. Saarbrucken, Germany: VDM Verlag.

De Bot, K. (2007). Dynamic systems theory, lifespan development and language attrition. In B. Köpke, M. S. Schmid, M. Keijzer, \& S. Dostert (Eds.), Language attrition: Theoretical perspectives (pp. 53-68). Amsterdam, the Netherlands: John Benjamins. 
De Jong, L. (1980). Het koninkrijk der Nederlanden in de Tweede Wereldoorlog. Deel 10b. Het laatste jaar. The Hague, the Netherlands: Staatsdrukkerij.[AQ: 23]

Dreifus, C. (2011, May). The bilingual advantage: A conversation with Ellen Bialystok. The New York Times, Retrieved from: http://www.nytimes.com/2011/05/31/science/31 conversation.html

Ellis, R. (1994). The study of second language acquisition. Oxford, UK: Oxford University Press.

Fase, W., Jaspaert, K., \& Kroon, S. (1992). Maintenance and loss of minority languages. Amsterdam, the Netherlands: John Benjamins.

Fishman, J. (1966). Language loyalty in the United States. The Hague, the Netherlands: Mouton.

Fishman, J. (1991). Reversing language shift. Clevedon, UK: Multilingual Matters.

Hulsen, M. (2000). Language loss and language processing: Three generations of Dutch migrants in New Zealand (PhD thesis). University of Nijmegen, the Netherlands.

King, M. (2003). The penguin history of New Zealand. Auckland, New Zealand: Penguin Books.

Köpke, B., Schmid, M., Keijzer, M., \& Dostert, S. (2007). Language attrition: Theoretical perspectives. Amsterdam, the Netherlands: John Benjamins.

Kuiper, K. (2004). Etnografisch onderzoek en taalverschuiving: Nederlandse taalreservaten in Christchurch, Nieuw-Zeeland. Nederlandse Taalkunde, 9, 132-143.[AQ: 24]

McCaffery, J. (1998, October). Blessed with bilingual brains. Paper presented at the Innovations in Education Conference, Mangere, New Zealand.

Pauwels, A. (1986). Immigrant dialects and language maintenance in Australia: The cases of the Limburg and Swabian dialects. Dordrecht, the Netherlands: Foris.

Roberts, M. (1999). Language maintenance and shift in the Gujarati, Dutch and Samoan communities of Wellington (Unpublished doctoral thesis). Victoria University of Wellington, Wellington, New Zealand.

Sachtleben \& Crezee (in press). Where are you from? Host expectations and migrant identity.[AQ: 25]

Schmid, M. (2004). A new blueprint for language attrition research. In M. Schmid, B. Köpke, M. Keijzer, \& L. Weilemar (Eds.), First language attrition (pp. 349-363). Amsterdam, the Netherlands: John Benjamins.

Schouten, H. (1992). Tasman's legacy: The New Zealand-Dutch connection. Wellington, New Zealand: New Zealand-Netherlands foundation.

Seebus, I. (2008). 'Dinkum Dutch Aussies': Language and identity among elderly Dutch-Australians (Unpublished $\mathrm{PhD}$ thesis). Monash University, Melbourne, Australia.

Smolicz, J. (1992). Minority languages as core values of ethnic cultures: A study of maintenance and erosion of Polish, Welsh and Chinese languages in Australia. In W. Fase, K. Jaspaert, \& S. Kroon (Eds.), Maintenance and loss of minority languages (pp. 227-305). Amsterdam, the Netherlands: John Benjamin.

Taumoefolau, M., Starks, D., Davis, K., \& Bell, A. (2002). Linguists and language maintenance: Pasifika language in Manukau, New Zealand. Oceanic Linguistics, 41, 15-27.

Vossestein, J. (2005). Dealing with the Dutch. Amsterdam, the Netherlands: Koninklijk Instituut voor de Tropen.

\section{About the author \\ [AQ: 26]}

